\title{
The Effect of Model Problem Based Learning (PBL) Assistance of Prezi Media on Student Learning Outcomes in Colloid Materials
}

\author{
Nurul Mamelya Harahap \\ Program of Postgraduate, \\ Universitas Negeri Medan \\ Medan, Indonesia \\ email : harahapame19@gmail.com
}

\author{
Wesly Hutabarat \\ Program of Postgraduate, \\ Universitas Negeri Medan \\ Medan, Indonesia
}

\author{
Saronom Silaban \\ Program of Postgraduate, \\ Universitas Negeri Medan \\ Medan, Indonesia
}

\begin{abstract}
Problem Based Learning (PBL) is one of the cooperative learning models that is often used today. To provide the best results, research is needed with PBL learning models assisted by instructional media that are easy and attract students to understand the material. This study aims to determine the effect of the Problem Based Learning (PBL) model assisted by Prezi media with the Prezi-assisted Direct Instruction Learning model on student learning outcomes in colloidal material. The research will be conducted in MAN 2 Medan Model. The method used in this study is quasi experiment. The research sample was taken by purposive sampling technique and obtained a sample consisting of experimental classes which were taught by PBL learning models assisted by media prezi and control classes which were taught with Direct Assistance-assisted media prezi models. The research instrument in the study consisted of 25 test questions in the form of multiple choice questions, which had previously been through validation tests, difficulty level tests, different power tests, and reliability tests. Then the data is analyzed by calculating homogeneity and normality. And the research hypothesis was tested using 2-way ANAVA statistical test. The results obtained are the effect of the Problem Based Learning (PBL) model assisted by Prezi media with the Preziassisted Direct Instruction Learning model on student learning outcomes in colloidal material.
\end{abstract}

Keywords- Development of PBL Models, Prezi Media, Motivation, and Student Learning Outcomes.

\section{INTRODUCTION}

A fairly basic problem in natural science education in high school as a pre-academic education is the curriculum [1], learning, and school management that are less conducive to optimal learning will have an impact on student learning processes that are of low quality. This process is considered unable to foster student creativity, because more learning provides students with a large amount of theoretical knowledge and memorization with a solid material load. The Government's commitment and seriousness to improve the education system and curriculum in Indonesia began to show a bright spot, through the 2013 curriculum. Basically 2013 curriculum-based learning shows that learning is studentoriented rather than teacher. This aims to support the student learning process, providing a broad space for students to think, learn and discover. Thus, a good curriculum system needs to be supported by a good learning process, so that the achievement of learning activities and student learning outcomes is more effective, and one element that can help make it effective is the Learning Model [2]. The results of observations carried out, showed that the learning activities of Chemistry in MAN 2 Model Medan were not going well. It was found that students were less interested in learning Chemistry, which was based on the lack of learning models used by teachers, students were always treated with difficult concepts, and subject matter was still abstract because it had not been directed to analyze problems and find specific products. To overcome this problem the teacher can use the Problem Based Learning model. The Problem Based Learning model is an active learning model, to overcome practical problems that arise as a result of conventional / traditional learning models, which are unable to prepare students for solving complex problems and students' inability to transfer learning acquired in the classroom to real-world situations [3]. One effort to streamline the learning process and facilitate the delivery of material to students can be done with the use of Prezi Media. According to Rosadi [4] media prezi is one of the online presentation slide making software. Unlike power point, Prezi provides more free space to pour creations into making presentation slides. With the help of this prezi media it is expected that students will be easier to understand in the lessons delivered [5]. Based on the description above, the purpose of this study was to determine whether there was a difference in the effect of the Problem Based Learning model assisted by the prezi media with the Direct Intraction learning model assisted by the media prezi on student learning outcomes in colloid material. 


\section{RESEARCH METHOD}

The study was conducted in class XI MAN 2 MODEL MEDAN even semester, 2017/2018 school year. Data collection time began in April 2018 to June 2018. The population in the study were all students of class XI Science, while the sample was determined purposively sampling Experimental class is the class that was taught by Problem Based Learning (PBL) model with Prezi media. The control class is a class that is taught by the Direct Instruction model with Prezi media.

The method used in this study is quasi experiment. Data collection instruments in this study were learning outcomes test used in this study is an objective test that has been validated by expert validators in multiple choice form consisting of 25 questions, based on the cognitive domain of Bloom's taxonomy which includes C1-C5 knowledge. Research Instrument Trial Before the test was used, the characteristics of the test were first seen, including: 1) test item validity, 2) test reliability, 3) level of test difficulty, and 4) different power. Data analysis techniques used to achieve research objectives include: 1) measuring students' initial abilities with N-Gain. The category of learning achievement improvement of students after applying comic media was measured by normality test $(\mathrm{N}$ - gain) with the normalized $\mathrm{N}$ gain value classification can be seen from the following criteria:

criteria:

$\mathrm{N}$-gain $<0.3$ : low category

$0.3 \leq \mathrm{N}$-gain 7 0.7: medium category

N-gain $>0.7$ : high category

\section{RESEARCH RESULTS AND DISCUSSION}

The initial research activity, the entire population is all students of class XI MAN 2 MODEL MEDAN even semester 2017/2018 academic year and class X IPA 1 as the control class. The population in the study were all students of class XI IPA, while the sample was determined purposively sampling. Experimental classes were classes that were taught by the Problem Based Learning (PBL) model assisted by Prezi media. The control class is a class that is taught by the Direct Instruction model with Prezi media.

Based on Table 1 it can be seen that the pretest, posttest and N-gain data of the experimental class which was taught by PBL model assisted by media prezi and the control class that was taught by the DI model assisted by media prezi had a probability value of sig.> A (0.05). Thus it can be concluded that the pretest, posttest and $\mathrm{N}$-gain data are normally distributed.
TABLE 1. Test for Normality of Control and Experiment Classes.

\begin{tabular}{|c|c|c|c|c|}
\hline Class & Data & Sig & $\alpha$ & Description \\
\hline \multirow[t]{3}{*}{$\begin{array}{l}\text { Experi } \\
\text { ment }\end{array}$} & pretest & 0,056 & 0,05 & $\begin{array}{c}\text { Data } \\
\text { normally }\end{array}$ \\
\hline & posttest & 0,052 & 0,05 & $\begin{array}{c}\text { Data } \\
\text { normally }\end{array}$ \\
\hline & N-gain & 0,339 & 0,05 & $\begin{array}{c}\text { Data } \\
\text { normally }\end{array}$ \\
\hline \multirow[t]{3}{*}{ Control } & pretest & 0,299 & 0,05 & $\begin{array}{c}\text { Data } \\
\text { normally }\end{array}$ \\
\hline & posttest & 0,063 & 0,05 & $\begin{array}{c}\text { Data } \\
\text { normally }\end{array}$ \\
\hline & N-gain & 0,268 & 0,05 & $\begin{array}{c}\text { Data } \\
\text { normally }\end{array}$ \\
\hline
\end{tabular}

\section{A. Hypothesis Test}

The hypotheses tested in this study include: (1) differences in the effect of PBL models assisted by prezi media and DI models assisted by prezi on students' chemistry learning outcomes. Hypothesis testing using two-way variance analysis (ANAVA) technique on N-gain data with the help of SPSS 21.0 program.

Learning outcomes taught by the PBL model assisted by the media prezi and the model assisted by the media prezi are presented in Table 2.

TABLE 2. Results of average N-gain based on learning evaluation results (PBL assisted media prezi models and DI models) assisted by prezi media on chemistry teaching.

\begin{tabular}{cccc}
\hline $\begin{array}{c}\text { Learning } \\
\text { Model }\end{array}$ & $\begin{array}{c}\text { Avera } \\
\text { ge }\end{array}$ & \multicolumn{2}{c}{$\begin{array}{c}\text { Interval } \\
\text { confidence }\end{array}$} \\
\cline { 3 - 3 } & & $\begin{array}{c}\text { Lowest } \\
\text { Limit }\end{array}$ & $\begin{array}{c}\text { Highest } \\
\text { Limit }\end{array}$ \\
PBL & 0,771 & 0,752 & 0,791 \\
$\begin{array}{c}\text { assisted } \\
\text { prezi }\end{array}$ & & & \\
$\begin{array}{c}\text { Direct } \\
\text { Instruction } \\
\text { assisted } \\
\text { prezi }\end{array}$ & 0,614 & 0,596 & 0,632 \\
\hline
\end{tabular}

Learning with PBL model assisted by media prezi obtained an average value of learning outcomes of 0.771 higher than students who were taught with the DI model assisted by media prezi with an average value of 0.614 . Thus it is clear that there are differences in learning outcomes learned by the PBL model assisted by media prezi and the media model assisted by the prezi DI.

The difference between the influence of PBL models assisted by media prezi and the media model assisted by the DI prezi model on student learning outcomes is shown in Figure 1 


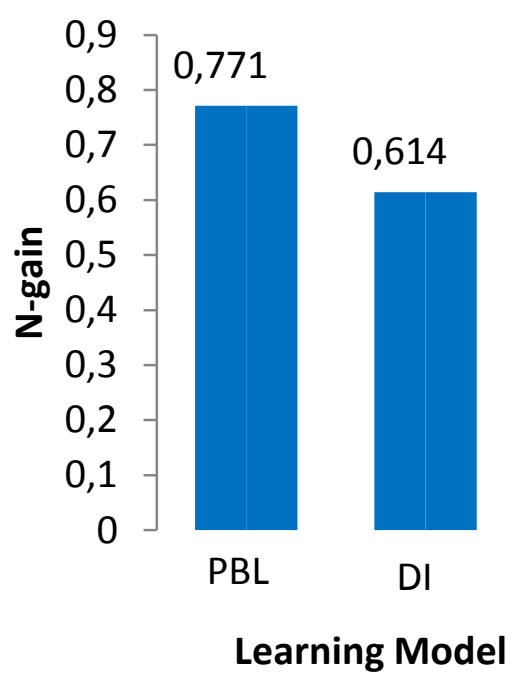

Fig 1. Graph of average N-gain taught by PBL model assisted by the media prezi and the media model of the prezi assisted DI.

\section{CONCLUSION}

Based on data processing and discussion of the results of research conducted, it can be concluded as follows: There is a difference in the effect of Problem Based Learning (PBL) models assisted by Prezi media and Direct Instruction (DI) models assisted by Prezi media on student learning outcomes $(\mathrm{p}=0,000<0,05)$. Students who were taught with PBL models assisted by Prezi media obtained an average score of 0.771 higher learning outcomes compared to students who were taught with the DI model assisted by Prezi media with an average value of 0.614 .

\section{REFERENCES}

[1] Pratama, A. Ashadi, N.Y. Indriyanti (2017). Efektivitas Penggunaan Modul Pembelajaran Kimia Berbasis Problem-Based Learning (PBL) Untuk Meningkatkan Kemampuan Berpikir Kritis Siswa pada Materi Koloid SMA Kelas XI. Prosiding Seminar Nasional Pendidikan Sains (SNPS) 2017. 150-156

[2] A.G.P. Putra, S. Bektiarso, R.D. Handayani (2017), Pengaruh Model Problem Based Learning (PBL) Terhadap Hasil Belajar dan Keterampilan Proses Sains dalam Pembelajaran Fisika di SMA (Kelas X SMA Negeri 3 Jember). Jurnal FMIPA. Universitas Jember

[3] Cindy E, dan Silver H, (2004), Problem-Based Learning: What and How Do Students Learn? Educational Psychology Review, 16 (3); 235-265

[4] E. Epinur, S. Wilda, A. Adriyani (2014). Pengembangan Media Pembelajaran Kimia Pada Materi Elektrokimia Untuk Kelas XII SMA N 8 Kota Jambi dengan Menggunakan Software Prezi. Journal of The Indonesian Society of Integrated Chemistry. 6, 13-22

[5] N.M. Rosadi (2012). Pengaruh Sikap Pada Mata Pelajaran Kimia Dan Konsep Diri Terhadap Prestasi Belajar Kimia, Jurnal Formatif. 2, 218226 